\title{
Evaluating the Effectiveness of Integrating Reading and Writing Pedagogy in EFL Setting and Teachers' Perceptions
}

\author{
Hailah Alhujaylan ${ }^{1}$ \\ ${ }^{1}$ Assistant Professor, Department of English Language and Translation, College of Science and Arts in Buraidah, \\ Qassim University, Saudi Arabia \\ Correspondence: Hailah Alhujaylan, Assistant Professor,Department of English Language and Translation, \\ College of Science and Arts in Buraidah, Qassim University, Saudi Arabia
}

Received: March 30, 2020

Accepted: April 25, 2020

Online Published: April 28, 2020

doi: $10.5539 /$ elt.v13n5p177

URL: https://doi.org/10.5539/elt.v13n5p177

\begin{abstract}
The present research argues that the current segregation between the reading and writing skills courses in EFL classes is a hard obstacle in developing the reading ability and writing skills proficiency in Saudi students at the graduate level. The sample included 64 undergraduate female students of a Saudi University, divided equally into the control group and the experimental group. A pre-test and post-test research design was used to collect the quantitative data. Two-tailed t-tests were applied to verify the results. The analysis of elicited data indicates significant progress in the experimental group's mean scores of the post-test when compared to the pre-test at $\mathrm{p}<.05$. The study finds that integrated-skills teaching pedagogy has a significant impact on students' reading and writing proficiency over a short time. A structured questionnaire was administered on $n=28$ language teachers to identify teacher's perceptions regarding the integrated interpretation and writing courses. They expressed their dissatisfaction with the current segregated reading and writing courses and the learning outcomes. Most experienced teachers expressed a positive attitude towards the integration of these skills. Based on the findings, the researcher recommends incorporating integrated skills pedagogy in teaching reading and writing skills at the university level to enhance the students' performance.
\end{abstract}

Keywords: integrated reading and writing skills, EFL, segregated skills, teaching pedagogy, teachers' perceptions

\section{Introduction}

Learning a foreign language has always been challenging for most of the college students, specifically in the Arab region. The English reading and writing skills are considered the two most demanding; however, exciting skills. Teaching and learning of these skills need a natural sequence (Krashen \& Terrell, 1995) and thematic links because this sequence builds a strong positive relationship in acquiring the target language. The traditional segregated-skills teaching style cannot create this sequence. Modern ELT demands the integration of English reading and writing skills to ensure better and more significant learning outcomes. The idea of the integrated-skill teaching approach is not new and has long been discussed and supported by various researchers ( Shanahan \& Lomax, 1988; Fitzgerald \& Shanahan, 2000; Al-Dosari, 2016). The Integrated-skills teaching pedagogy is a natural learning approach because it helps in accelerating the development of communicative skills in EFL students (Li \& Yang, 2014; Mekheimer \& Aldosari, 2013; Pysarchyk \& Yamshynska, 2015; Pardede, 2017). Li \& Yang (2014) write, "Reading and writing are both the communicative means between the reader and the writer" (p. 68).

According to Pardede (2017), "To enable the EFL students to develop their knowledge of English and their competence to use it in real communication, implementing the integrative skills approach is unavoidable" (p. 218). Pysarchyk \& Yamshynska affirm that the main aim of teaching Foreign Language (FL) is "communicative competence," and for that, they believe, "integrating skills is essential" (p. 78).

It is noteworthy that the goal mentioned above is the required learning outcome (LOC) by the Saudi Education Ministry. The main objective of teaching the English reading and writing courses at graduation level in Saudi universities is to prepare the students to deal with open-ended communicative tasks. By the end of the academic session, they should have mastered the essential skills to interact and communicate individually and collaboratively as team members in the Saudi community. Currently, structurally segregated reading and writing 
courses are taught in most of the Saudi universities. The present study will not focus on weakness and drawbacks of these courses; instead, it aims to bring into light the usefulness of integrated reading and writing courses in Saudi Arabia.

The study aims to investigate how EFL students' writing performance and their overall scores in writing are affected when the composing process has a thematic link to a reading passage, compared to the paper on given topics without no or little reading practice. The findings of the research will bring further understanding of the most appropriate and effective ELT methodology to the Saudi academic community. The researcher also suggests innovative strategies for teachers to prepare the students to respond to a reading text in writing in a learning environment.

\section{Literature Review}

\subsection{The Relationship between Reading and Writing Skills in EFL Classroom}

Good readers make good writers. Reading plays a fundamental role in writing instruction (Bazerman, 1980; Krashen, 1982; Smith, 1983; Greene, 1992; Fitzgerald \& Shanahan, 2000; Durgunoglu et al., 2002; Hao \& Sivell, 2002; Shanahan, 2006; Koons, 2008; Tsai, 2006; Almansour \& Al-Shoramn, 2014; Cho \& Griffler, 2015; Al-Dosari, 2016; Park, 2016; Choi, Moon, Paek, \& Kang, 2018 Andersen, Christensen, Nielsen, Thomsen, Østerbye, Rowe, (2018).The research also supports the argument that reading books assist students "learn naturally, from context, and provide[s] excellent models of written English" (Elley \& Mangubhai, 1983, p. 56).

Several studies have shown an explicit relationship between the two essential skills of human language. According to Durgunoglu et al., 2002, "Language and literacy (reading and writing) development are closely intertwined processes" (p. 81). They posit that the development of one skill facilitates the learning of the other. Tsai (2006) believes that fluent L2 acquisition requires a reciprocal reading and writing connection. Smith (1983) comments that knowledge easily transfers if there is a thematic relationship between reading and writing. According to Miller et al., 2012:

Writing tasks involve reading source documents to gather information, mobilizing background knowledge, evaluating sources read, thinking about purpose, and reviewing what has been written - mainly reading tasks. Similarly, reading often involves writing summaries or constructing written responses to questions (p. 4).

Hao \& Sivell (2002) support the integrated reading and writing connection by arguing the division in teaching reading and writing, which hinders the development of both skills. Tsai (2006) also believes that reading and writing "share similar properties" and further concludes, "both reading and writing are acts with communicative purposes and are inseparable" (para.18). Tsai (2006) does not favor the separate teaching of both skills because this kind of teaching approach is an obstacle in fluent learning of FL reading and writing.

Krashen (1993) asserts that input for writing is provided by reading. Dubin and Olshtain (1980) have stated the same concept as "a written communication model" (p.354). In this model, they present the writing process at the production end and the reading process at the receiving end. The reader connects to both ends by the text. Various empirical studies give evidence that the productive capability of language usually aids in the strong development of receptive skills. (Dubin \& Olshtain1980; Greene, 1992; Fitzgerald \& Shanahan, 2000; Mekheimer \& Aldosari, 2013; Motušić, 2014; Golkova \& Hubackova,2014; Pysarchyk \& Yamshynska, 2015; Sreena \& Ilankumaran, 2018). Greene (1992) states, "Reading and writing are complementary processes of composing meaning; discussions of how a sense of authorship can inform reading are underspecified" (p. 151). Pysarchyk \& Yamshynska (2015) assert, "Development of reading and writing skills requires persistent and continual study" (p. 78). Therefore, students can master these skills better and faster when learned together and have improved results on the literacy process.

The L1 reading influence on L2 writing is hard to ignore (Tudor \& Hafiz, 1989; Krishan, 1982; Cho \& Griffler, 2015). For composing a good piece of paper, a student needs to have prior knowledge about the topic which s/he may have acquired in the first language. Krishan (1982) draws attention towards the role of early language reading comprehension, which has a sound impact on second language reading comprehension and composing process. According to Krishan (1982), reading provides the basis for this required knowledge or "world knowledge" (Fitzgerald \& Shanahan, 2000, p. 40), and learners use this knowledge in building sentences and developing the structure for composition. Nevertheless, good readers of the first language can explore a variety of topics to write in the second language.

Students can expand this specific knowledge to communicate with their social community. In this way, they have better "communicative competence (grammatical/linguistic competence, strategic competence, sociolinguistic competence, and discourse competence)" (Pardede, 2017, p. 221). Fitzgerald \& Shanahan (2000) explain the 
three basic approaches to reading and writing connection. One of these is the rhetorical approach in which Fitzgerald \& Shanahan (2000) take reading and writing as communication activities where the reader is a sender, and the writer is a receiver to get perception and knowledge.

Though reading plays a vital role in enhancing one's writing skills, there comes a stage after a great deal of receptive experience when the writer's creativity, imagination, and rational take the primary position instead of reading material. That is why, in an EFL classroom, students may interpret a reading passage differently than their peers. Reading is a helpful instrument for early writers; however, an experienced writer may not depend on the reading material. There is a dare need to design such courses and materials which can train students to compose their thoughts and feel free to write independently.

\subsection{The Role of Reading in Writing Instruction in an EFL Classroom}

A classroom teaching pedagogy itself is least worthy unless combined with practice and real-life experience in and outside the classroom. Krashen \& Terrell (1995) assert for the natural approach and state that comprehensible input is "crucial ingredient in language acquisition" (p. 1). In the integrated-skills teaching approach, students understand and decode the message. Then they learn to apply it to writing for the productive output. They use various skills that they have developed in reading comprehension and vice versa. From this point, it is essential to note that reading helps learners' minds to grow in a multitude of ways (Cunningham \& Stanovich, 2001), which leads them to think critically on a topic.

For EFL, critical thinking (CT) is among one of the essential 4Cs (AL Zahrani \& Elyas, 2017), and receptive skills proficiency can develop students' critical thinking. They further mention, "A significant association has been noted between the critical thinking capabilities of TOEFL test takers and their scores on the reading section of the test" (Kamali, 2011 as cited in Al Zahrani \& Elyas, 2017, p. 137). In an EFL classroom, reading initiates students to think critically, and they are in a better position to develop their writing abilities (Cavdar \& Doe, 2012). Tierney, O'Flahavan \& McGinley (1989) affirm reading and writing as a representative means "to think and learn" (p. 137). Li \& Yang (2014) believe "Reading-to-write involves critical thinking and creative writing which are always the focus of philosophy, linguistics and writing studies" (p. 67).

Teachers can motivate their students by the ideas and style given in the passages to learn the writing techniques and stylistic devices. Furthermore, during reading comprehension exercises, improvements in the mind mapping process and argument analysis from different points of view can help in tasks' writing. Reading that aims for writing is an important technique that improves students' writing skills proficiency (Greene, 1992; Plakans, 2008; Li \& Young, 2014; Al-Mansour \& Al-Shorman, 2014). According to the Reading hypothesis in Krashen (1993), "We acquire writing style, the special language of writing, by reading" (p. 27). So, students can also improve and practice their writing style with reading extensively.

In an EFL classroom, integrated skills activities encourage class discussion and make reading a collaborative practice. Frank Smith (1983) considers language learning as "a collaborative activity" (p. 591). Collaborative Learning (CL) is regarded as a tool by many EFL teachers to enhance the learning capacity of their students (Amel, 2015). Reading practice in writing instruction creates a collaborative learning environment in a language classroom where students get the motivation to discuss their ideas. As a result, students work together on a given job, and writing turns into a collaborative task. They get open opportunities to participate and provide feedback on each other's work. Their interdependence makes them more confident and motivates them to move ahead in the learning process (Amel, 2015).

\subsection{Segregated Reading and Writing Skills Teaching-Challenges for EFL Students}

Al-Mansour \& Al-Shorman (2014) describe writing skills as "a powerful mean of communication, the core of education, and an important path of language learning" (p. 259) whereas reading is a complex skill for Arab students (AlKialbi, 2015; Muhammad \& Rashid, 2019). Excellent writing skills are a prerequisite for EFL students (Al-Mansour \& Al-Shorman, 2014). Learners give clear and concrete shapes and styles to their vague ideas by putting them down on paper.

However, writing is a challenging skill for EFL students (Cavdar \& Doe, 2012). Ong \& Zhang (2013) assert, "Writing is a difficult task because it is cognitively demanding" (p. 375). Not only in the Saudi context, throughout the globe, but EFL students also face many difficulties in excelling in their writing skills. According to IELTS test-taker performance 2017, test takers from $97.5 \%$ of countries (out of 40 ) had lower writing mean band scores compared to reading mean band scores.

EFL students struggle hard to get command over the grammatical structure and vocabulary to express their ideas, which are the reasons explained by Tangpermpoon (2008) to consider writing the most challenging language 
skill (Grabe, 2009). Additionally, students require the right combination of rhetorical patterns with advanced stylistic devices to develop their writing expertise (Al-Dosari, 2016). Generally speaking, students rarely master these techniques and strategies in their writing class because usually, the teachers focus on teaching the rules of individual skills, and the students aim to get high grades in midterm and final exams (Al-Nasser, 2015).

In the present time, discrete skills teaching is common in most of the universities in Saudi Arabia (Al-Dosari, 2016; Alrabai, 2016). Students who enter the university are underprepared to deal with the demanding values of learning reading and writing skills. Therefore, they face many problems in their academic careers (Khan, 2011; Javid \& Umar, 2014; Al-Nasser, 2015). Efforts in learning new techniques to deal with vocabulary for each skill and developing a content understanding for various subject-matter having no thematic link make reading and writing skills burdensome for the Saudi students (Javid \& Umar, 2014). When assigned a writing task, students face obscurity and nervousness, and they are hardly able to put their ideas in writing due to a lack of knowledge and mastery in applying the techniques. Most students ponder over the questions like: 'From where to begin and how to begin?' Necessarily, students should attain these skills at an earlier level of education (Khan, 2011; Javid \& Umar, 2014, Shukri, 2014; Al-Nasser, 2015; Alghonaim, 2018). Teaching and learning of these skills in the form of separate fields without getting desired results waste a colossal amount of time.

In an EFL classroom, reading comprehension exercises can lead to comprehension-oriented writing activities. The models in a writing classroom make a difference in the flow of the writing process (AlOmrani, 2014; Alghonaim, 2018). There are many pedagogical reasons to use models as writing samples. The models give information to the students, and they can also discuss the rhetorical patterns in the class (AlOmrani, 2014). Instead of focusing on specific rules on drafting and composing, which are quite often confusing for the students, the teacher can demonstrate and practice reading passages in class. However, Alghonaim (2018) finds out that students are most unlikely provided by a model of writing, based on pedagogical purposes of teaching writing through reading.

For EFL students, reading provides subtle models of various genres on which they can work collaboratively to enhance their writing. According to Greene (1992), "imitating models of well-wrought prose" provide students opportunities to learn "style, grace, and correctness" (p. 152). Students can use a model to identify the different rhetorical patterns and linguistics forms and infer the underlying meaning to precede on with composition. They feel supported and gain confidence in writing through this strategy (Alghonaim,2018). According to Benahnia (2016), "In a formal EFL/ESP learning situation, a writing activity can never be successful until the target language has been successfully exercised in speaking and also in reading activities" (p. 4).

It has become imperative that students should not only learn interpersonal communicative skills, but they should also receive meaningful and relevant content-area instruction to improve their language proficiency.

\section{The Study}

\subsection{Objectives of the Research}

The research has a three-fold aim of investigation:

- To shed light on the inadequacy of current reading and writing skills teaching pedagogy and approaches;

- To unfold the challenges which are faced by the students in a language classroom learning segregated skills;

- To measure the efficacy of integrating the reading and writing skills approach in higher levels of the undergraduate program at a Saudi University.

\subsection{Research Context}

This study was conducted on 64 female students of level II reading class, English Graduate Program. These students have already completed level I in their graduate program in the English department of a Saudi University. It is to notify that students seldom have or no writing practice in the reading courses of graduate programs. The researcher selected the reading class to see the usefulness of implementing the integrated reading and writing teaching pedagogy. However, the current prescribed courses are entirely different, and segregated, involving zero interaction among the students and teachers of these two courses.

For this research, the sample of 64 students was split randomly into two equally divided groups; 32 in the control group and 32 in the experimental group. Before the study began, a pre-test was conducted for both groups to ensure the internal validity of the results, and to rule out any possibility of pre-existing differences among the two groups.

Both groups received a post-test after one complete teaching semester. Finally, the results of the pre-test and 
post-test for the experimental group were analyzed to confirm whether there was a statistically significant improvement or not. All the tests had the same pattern with a reading text along with a thematically linked writing task.

\subsection{Data Collection}

A pre-test and post-test study design is auspicious for social sciences to investigate the effectiveness of any innovative teaching method. Therefore, the researcher has used this design to study the impact of the integrated-skills teaching approach.

To analyze the effectiveness of the integrated teaching method, students of the experimental group received a full semester integrated-skills teaching. In this intervention, a short thematic syllabus was designed. With each class session for the whole semester in 13 classes, they practiced two passages of 500-600 words for reading comprehension. The students wrote essays on thematically linked topics after completing reading the passages and reading comprehension exercises. Table 2 summarizes the treatment pattern.

Table 1. The Treatment Pattern

\begin{tabular}{cccc}
\hline Control Group & Pre-test & No Intervention & Post-test \\
\hline Experimental Group & Pre-test & Intervention & Post-test \\
\hline
\end{tabular}

For literacy practice, the researcher provided a set of supplementary material on selected thematically-related reading passages from authentic newspapers, magazines, and books. The primary purpose was to develop content awareness and increase vocabulary volume. The expansion activities, linked to multiple class activities, were conducted in pairs with the experimental group.

The experimental group was encouraged to identify the grammatical and lexical features of the text for later writing practice. The learned vocabulary and content forms of the text were clear enough for them to respond in writing. This part of the syllabus provided a natural and more informative foundation for the students to compose their ideas by synthesizing information from the given reading passages. Students received online assignments to practice their writing after reading and researching the topics.

\subsection{The Intervention Plan}

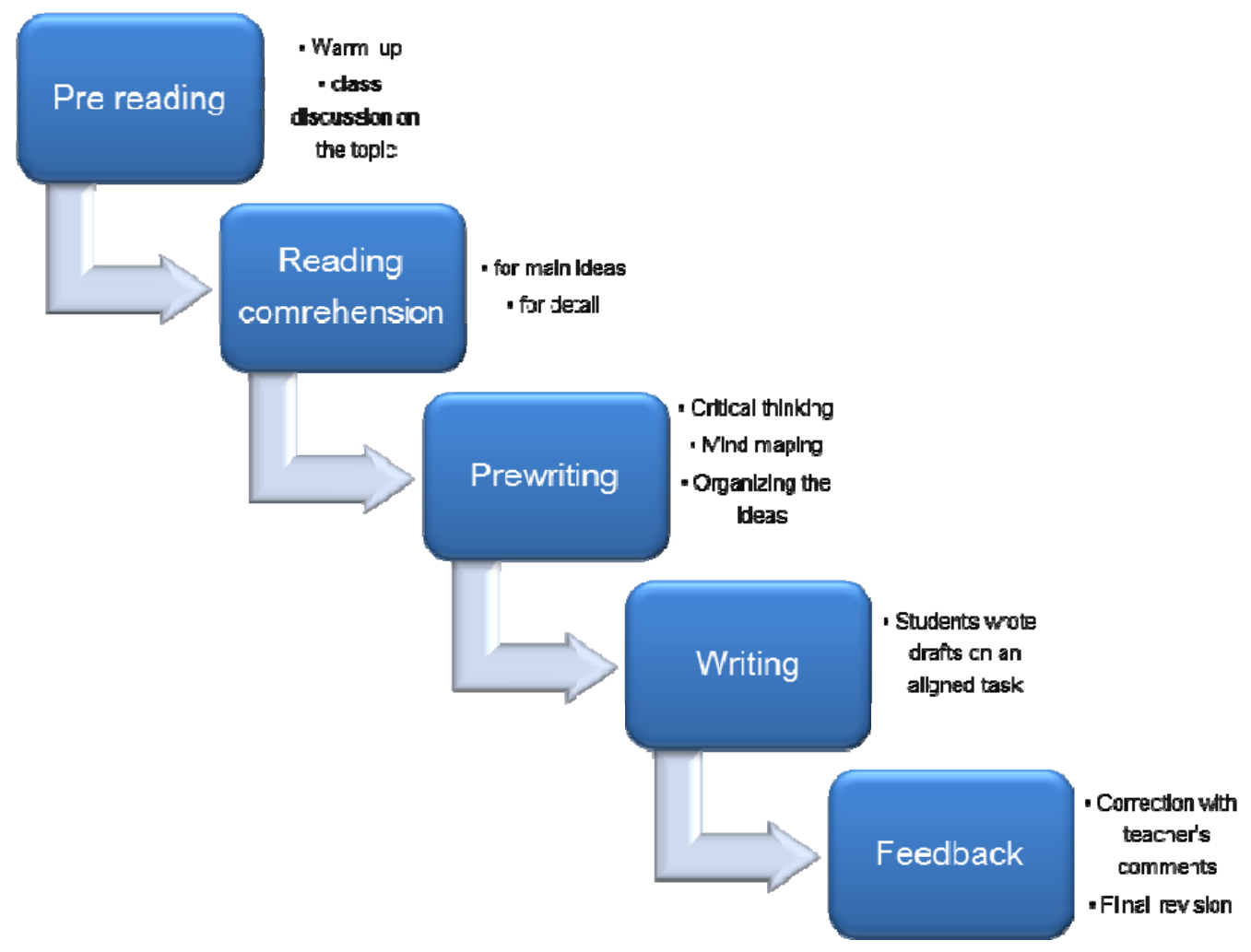

Figure 1. The Intervention plan 


\subsection{Hypotheses}

$\mathrm{H}_{0}$ : There will be no significant difference in the mean scores of control and experimental groups after the usage of an integrated reading-writing approach.

$\mathrm{H}_{\mathrm{a}}$ : There will be a significant difference in the mean scores of control and experimental groups after the application of an integrated reading-writing approach.

\section{Results}

Independent sample t-tests ( 2 tailed) were applied to find out the differences between the control group and the experimental group.

\subsection{Group-wise Comparison}

To ensure the internal validity of the results and rule out any possibility of pre-existing differences between the control and experimental groups, a pre-test for both groups was conducted, which comprised of a reading text linked thematically to a writing task.

\subsubsection{Pre-test of Control and Experimental Groups}

The descriptive statistics and results obtained from an independent samples t-test (2-tailed) are summarized in table 2.

Table 2. Descriptive statistics and independent samples t-test (2-tailed) results of Pre-test

\begin{tabular}{ccccccccc}
\hline Groups & $N$ & Mean & $S D$ & SE Mean & t-value & $d f$ & $p$-value & Sig. level \\
\hline Control & 32 & 23.47 & 3.927 & 0.69 & 0.21 & 62 & .832 & 0.05 \\
Experimental & 32 & 23.25 & 4.273 & 0.76 & & & &
\end{tabular}

The results in table 2 show that the pre-test scores of the students in the control group $(M=23.47, S D=3.927)$ and experimental group $(M=23.25, S D=4.273)$ prove that there was no statistically significant difference at $\mathrm{p}<.05$ in their mean scores; $t(62)=0.21, p=.832$. Based on these results, it is determined that at this point, both groups had equivalent reading and writing skills, and the possibility of pre-existing differences among the students of both groups is ruled out. Furthermore, a line chart (Figure 2) is plotted, which visually shows the comparison of scores obtained by the students of both groups.

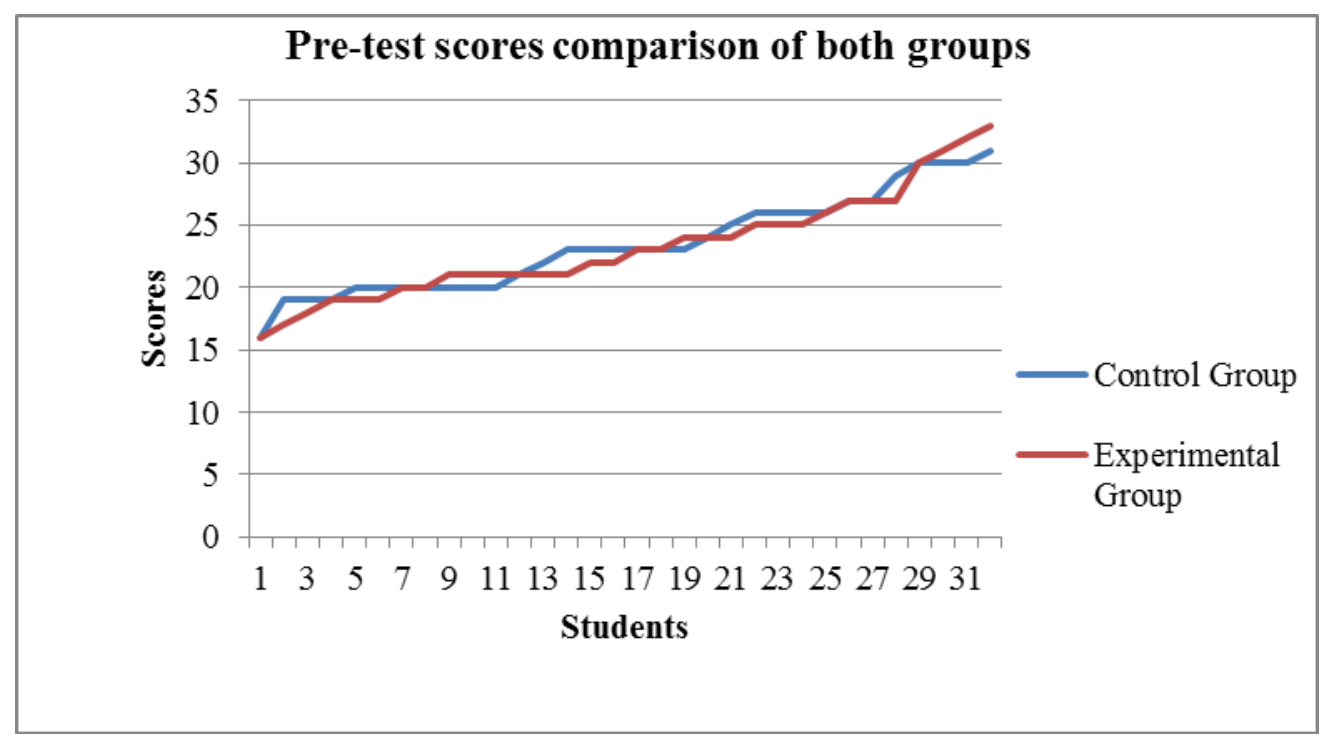

Figure 2. Pre-test scores comparison of control and experimental groups

\subsubsection{Post-test of Control and Experimental Groups}

After a complete teaching semester, a post-test was given to the control and experimental groups, which also comprised of a reading text linked thematically to a writing task, like the previous tests. The descriptive statistics and results obtained from an independent samples t-test (2-tailed) are summarized in table 3. 
Table 3. Descriptive statistics and independent samples t-test (2-tailed) results of Post-test

\begin{tabular}{ccccccccc}
\hline Groups & $N$ & Mean & $S D$ & SE Mean & $t$-value & $d f$ & $p$-value & Sig. level \\
\hline Control & 32 & 25.30 & 5.877 & 1.04 & -3.30 & 62 & \multirow{2}{*}{.002} & 0.05 \\
Experimental & 32 & 30.06 & 5.691 & 1.01 & & & & \\
\hline
\end{tabular}

According to the results in table 3, the post-test scores of the students in the control group $(M=25.30, S D=$ $5.877)$ and experimental group $(M=30.06, S D=5.691)$ prove that there was a statistically significant difference at $\mathrm{p}<.05$ in their mean scores; $t(62)=-3.30, p=.002$. Therefore, the researcher has solid evidence for the validity of her hypothesis, i.e., integrated reading-writing pedagogy does enhance the learning abilities of both skills.

The visual aid of the line chart (Figure 3) depicts the performance of students of control and experimental in the post-test.

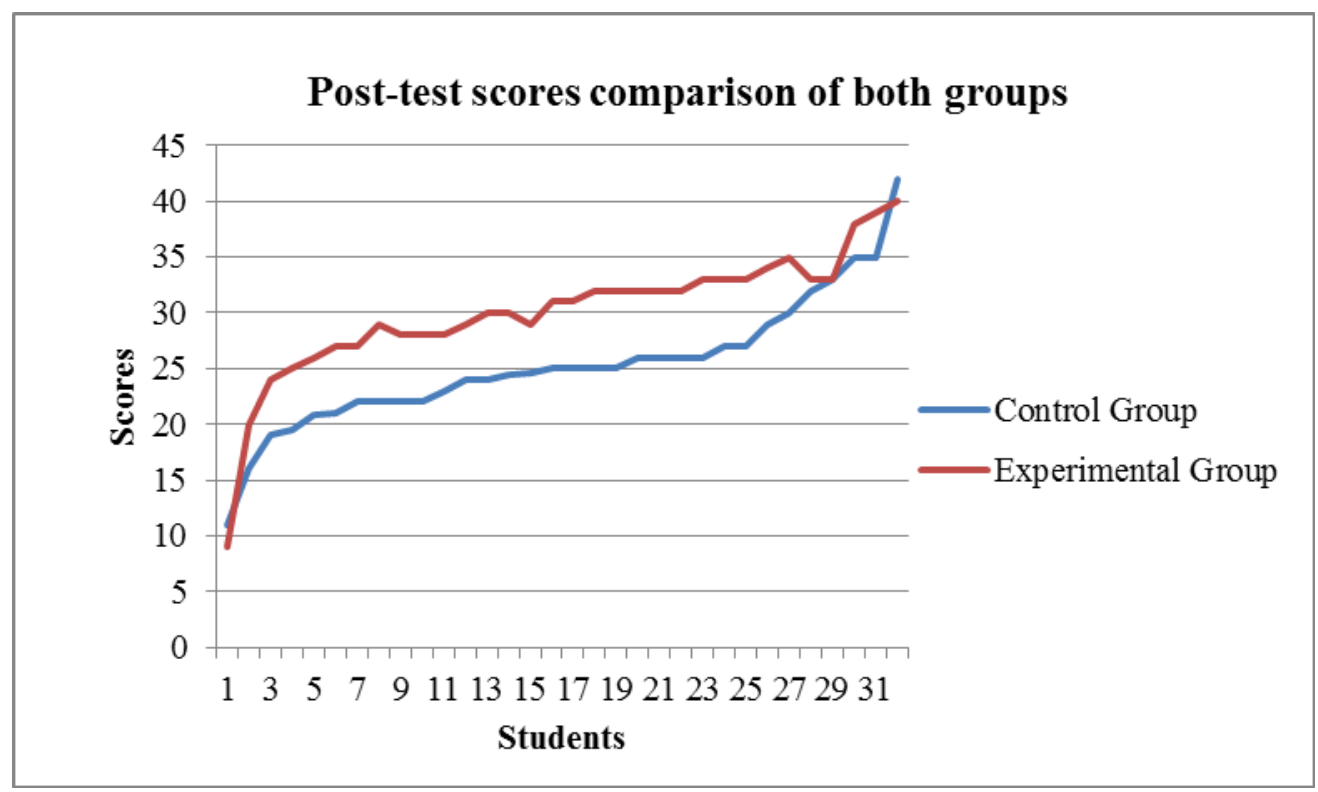

Figure 3. Post-test scores comparison of control and experimental group

\subsection{Test Wise Comparison}

To measure the significance of the overall progress of the experimental group throughout the complete teaching semester, a comparative analysis of its performance in the pre-test and post-test was done.

4.2.1 Pre-test and Post-Test Comparison of Experimental group

The descriptive statistics and results obtained from a paired sample t-test (2-tailed) are tabulated in table 4 .

Table 4. Descriptive statistics and paired sample t-test (2-tailed) results of Experimental Group

\begin{tabular}{ccccccccc}
\hline Assessment & $N$ & Mean & $S D$ & SE Mean & $t$-value & $d f$ & $p$-value & Sig. level \\
\hline Pre-test & 32 & 23.25 & 4.273 & 0.76 & -5.53 & 31 & .000 & 0.05 \\
Post-test & 32 & 30.06 & 5.691 & 1.01 & & & &
\end{tabular}

According to the results in table 4 , there was a statistically significant difference at $\mathrm{p}<.05$ in the pre-test scores $(\mathrm{M}=23.25, \mathrm{SD}=4.273)$ and post-test scores $(\mathrm{M}=30.06, \mathrm{SD}=5.691)$ of experimental group's students; $\mathrm{t}(31)=$ $-5.53, \mathrm{p}=.000$. The results confirm that the experimental group's students made some significant progress due to integrated reading and writing methodology over the complete semester.

\subsubsection{Pre-test and Post-Test Comparison of Control group}

A comparative analysis of the control group's performance in pre-test and post-test was done to see if its overall progress throughout the complete teaching semester was significant. The descriptive statistics and results obtained from a paired sample t-test (2-tailed) are tabulated in table 5. 
Table 5. Descriptive statistics and paired sample t-test (2-tailed) results of Control Group

\begin{tabular}{ccccccccc}
\hline Assessment & $N$ & Mean & $S D$ & SE Mean & $t$-value & $d f$ & $p$-value & Sig. level \\
\hline Pre-test & 32 & 23.47 & 3.927 & 0.69 & -1.52 & 31 & .139 & 0.05 \\
Post-test & 32 & 25.30 & 5.877 & 1.04 & & & & \\
\hline
\end{tabular}

The results in table 5 show that there was no statistically significant difference at $\mathrm{p}<.05$ in the pre-test scores $(M$ $=23.47, S D=3.927)$ and post-test scores $(M=25.30, S D=5.877)$ of control group's students; $t(31)=-1.52$, $p=.139$. Therefore, it can be safely said that the control group's students could not significantly improve their reading-writing skills because of the segregated teaching approach.

A structured questionnaire was administered electronically on twenty-nine teachers to identify the teachers' perceptions about the researched topic. The survey was sent by email and WhatsApp. All the teachers participated willingly and shared their valuable opinion.

\subsection{Questionnaire}

Table 6. Questionnaire Structure

\begin{tabular}{ccc}
\hline Section $A$ & Section $B$ & Section $C$ \\
\hline Biographical details & Current Reading and Writing & Integrated reading and writing \\
4 questions & Courses & Courses \\
& 8 questions & 7 questions \\
\hline
\end{tabular}

Table 6 shows the distribution of items in the questionnaire.

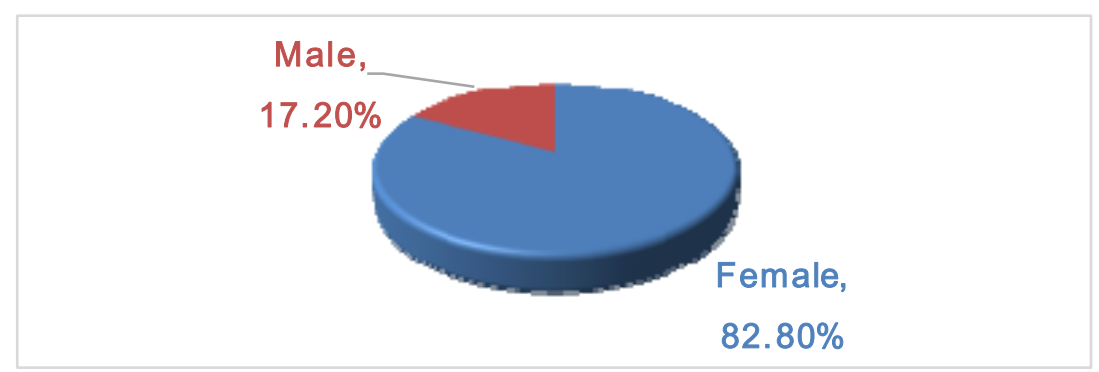

Figure 4. Distribution of male $\&$ female teachers

Figure 4 shows that $82.8 \%$ of the respondents were female teachers, compared to only $17.2 \%$ of male teachers.

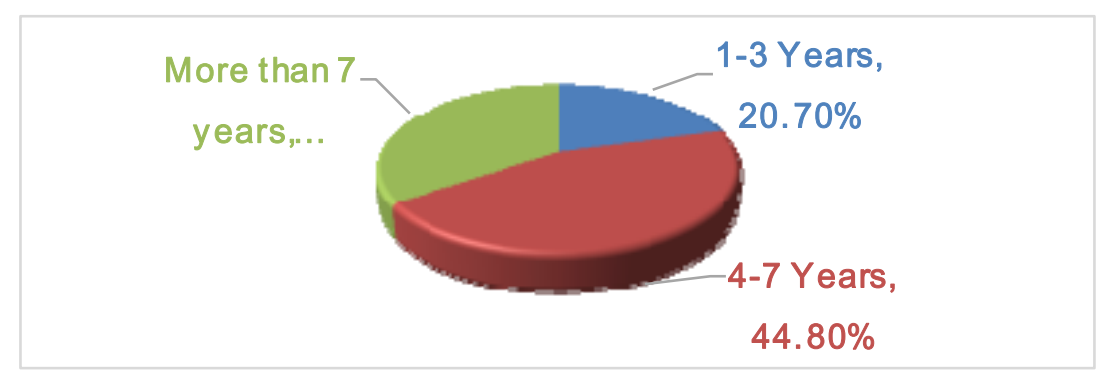

Figure 5. Work experience of the teachers

The pie chart in Figure 5 depicts that respondents who have worked at their respective universities for 1-3 years were $20.7 \%$, teachers with $4-7$ years were $44.8 \%$, and the percentage of senior teachers with seven or more years was $34.5 \%$. 


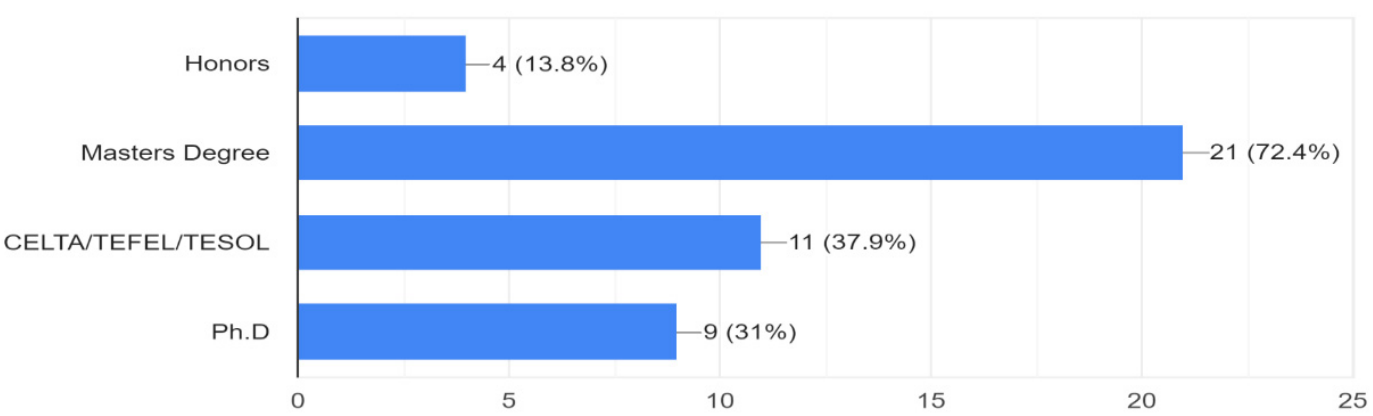

Figure 6. Qualification of the teachers

The qualification of the teachers varied considerably, of which $72.4 \%$ were Masters degree holders, followed by teachers with additional CELTA/TEFEL/TOSEL qualification (37.9\%), and $31 \%$ who held a Ph.D. degree. Furthermore, $13.8 \%$ of respondents held only an Honors degree.

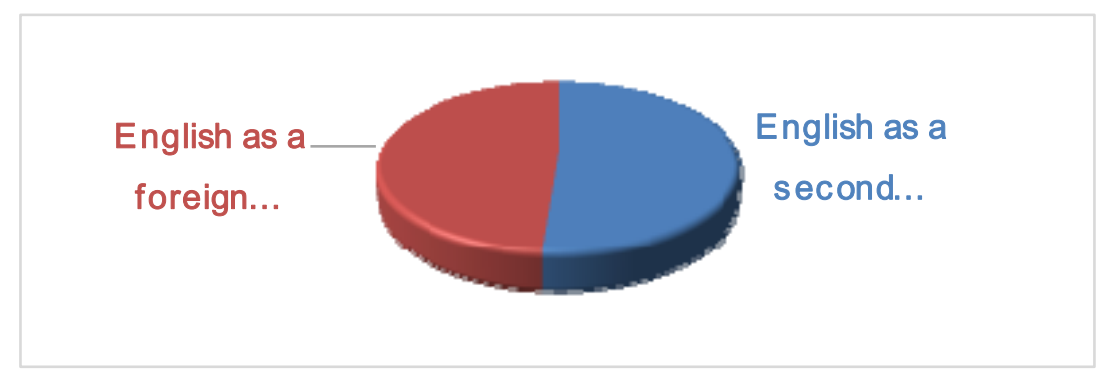

Figure 7. Status of English

The pie chart in Figure 7 shows that $79.1 \%$ of respondents were teaching ESL, and $75.4 \%$ of them were EFL

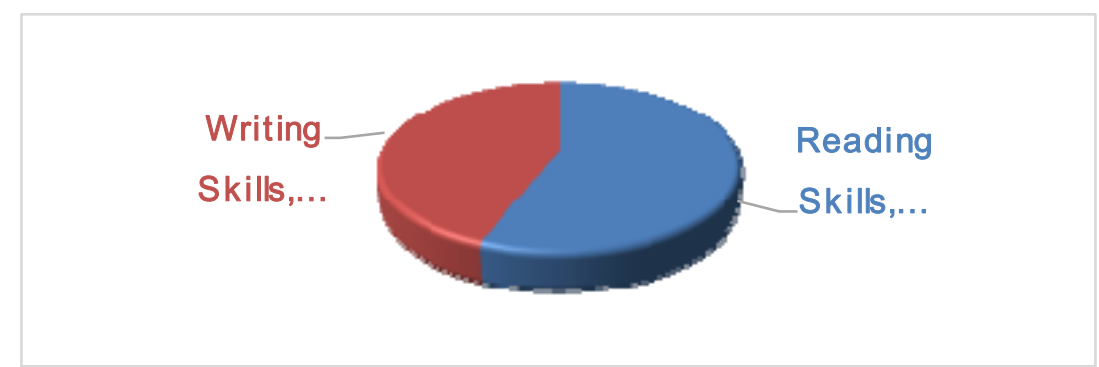

teachers at their respective universities when this survey was conducted.

Figure 8. Courses Taught

The pie chart shows that $96.6 \%$ of teachers teach the reading course, and $75.9 \%$ of teachers teach writing classes. Most teachers take both courses simultaneously.

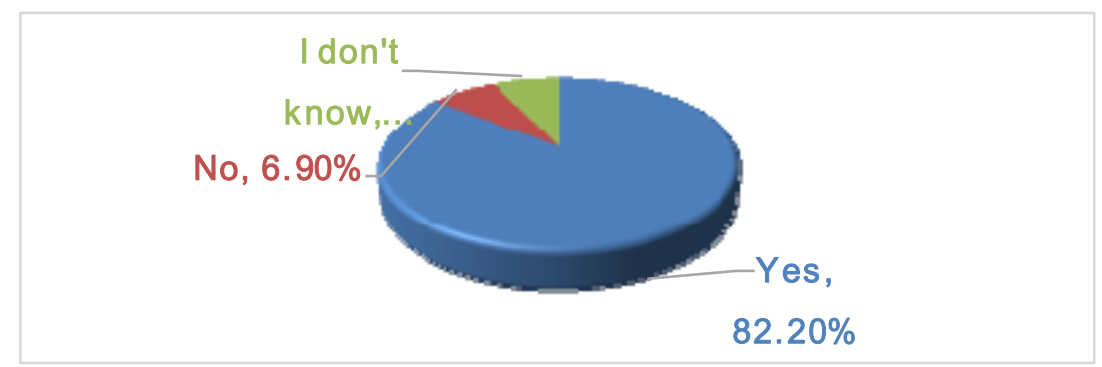

Figure 9. Segregated or integrated reading and writing courses

The pie chart shows respondents that $82.2 \%$ of teachers stated that they teach reading and writing as segregated courses, whereas $6.9 \%$ of teachers respectively said no and don't know. 
Table 7. Section B -Segregated Reading and Writing Courses

\begin{tabular}{|c|c|c|c|c|c|}
\hline Statements & $\begin{array}{c}\text { Strongly } \\
\text { disagree } \\
(\%)\end{array}$ & $\begin{array}{c}\text { Disagree } \\
(\%)\end{array}$ & $\begin{array}{c}\text { Natural } \\
(\%)\end{array}$ & $\begin{array}{c}\text { Agree } \\
(\%)\end{array}$ & $\begin{array}{c}\text { Strongly } \\
\text { agree } \\
(\%)\end{array}$ \\
\hline The current reading courses fulfill the students' needs. & 13.8 & 24.1 & 34.5 & 26.7 & 00 \\
\hline $\begin{array}{l}\text { After completing the course, students can read a given } \\
\text { text without any difficulty. }\end{array}$ & 6.9 & 55.2 & 10.3 & 27.6 & 00 \\
\hline The current writing courses fulfill the students' needs. & 34.5 & 34.51 & 13.8 & 13.8 & 3.4 \\
\hline $\begin{array}{l}\text { After completing the course, students can write an essay } \\
\text { on a given topic without any difficulty }\end{array}$ & 37.9 & 34.5 & 17.2 & 10.3 & 00 \\
\hline $\begin{array}{l}\text { I am satisfied with the learning outcomes of current } \\
\text { segregated reading and writing skills courses. }\end{array}$ & 17.2 & 44.8 & 17.2 & 10.3 & 00 \\
\hline
\end{tabular}

Table 7 shows that most teachers were not satisfied with the current reading and writing courses. They expressed their opinion that the present courses do not fulfill the students' needs and do not produce the required learning outcomes. Very few teachers agreed that after the completion of the courses, students could improve. (See a graphic illustration of each statement in Appendix 4)

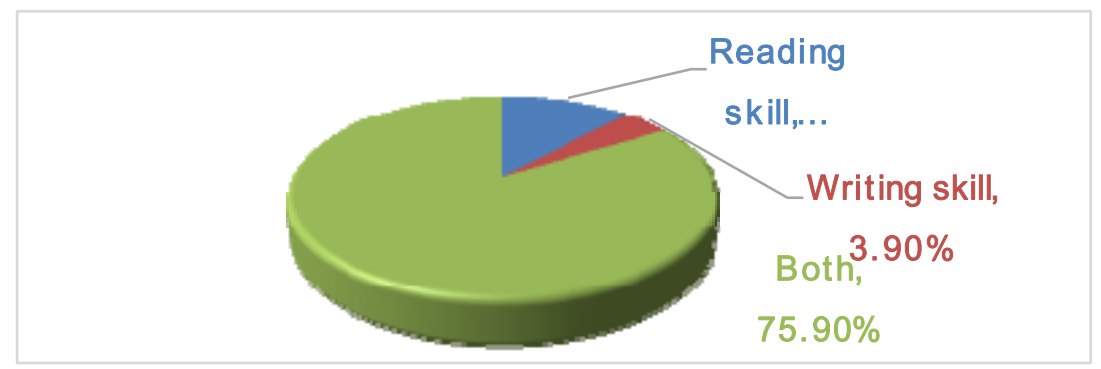

Figure 10. Skills that need improvement

Figure 10 shows that $75.9 \%$ of teachers thought that both reading and writing skills need improvement, $3.9 \%$ of teachers agreed that only writing skill needs improvement, whereas $10.8 \%$ believed only reading skills requires improvement.

Table 8. Section C -Integrated Reading and Writing Courses

\begin{tabular}{|c|c|c|c|c|c|}
\hline Statements & $\begin{array}{c}\text { Strongly } \\
\text { disagree } \\
(\%)\end{array}$ & $\begin{array}{c}\text { Disagree } \\
\text { (\%) }\end{array}$ & $\begin{array}{c}\text { Natural } \\
(\%)\end{array}$ & $\begin{array}{l}\text { Agree } \\
(\%)\end{array}$ & $\begin{array}{l}\text { Strongly } \\
\text { agree }(\%)\end{array}$ \\
\hline $\begin{array}{l}\text { It is better to offer integrated reading and writing } \\
\text { courses to enhance the students' performance. }\end{array}$ & 00 & 31.0 & 10.3 & 39.6 & 20.7 \\
\hline $\begin{array}{l}\text { Students can write better if the reading and writing } \\
\text { tasks are thematically aligned. }\end{array}$ & 6.9 & 17.2 & 10.3 & 48.3 & 27.6 \\
\hline $\begin{array}{l}\text { Students can understand the content better if the tasks } \\
\text { are integrated into reading and writing skills. }\end{array}$ & 00 & 13.8 & 17.2 & 41.4 & 27.6 \\
\hline $\begin{array}{c}\text { Students can work collaboratively in integrated reading } \\
\text { and writing classes. }\end{array}$ & 00 & 17.2 & 6.9 & 51.7 & 24.1 \\
\hline $\begin{array}{l}\text { The use of integrated reading and writing pedagogy } \\
\text { saves instructional time. }\end{array}$ & 00 & 6.9 & 20.7 & 41.4 & 31 \\
\hline $\begin{array}{l}\text { The integrated reading and writing pedagogy helps } \\
\text { students to learn the vocabulary that they need for the } \\
\text { writing task. }\end{array}$ & 00 & 17.2 & 3.4 & 41.4 & 37.9 \\
\hline $\begin{array}{c}\text { The integrated reading and writing pedagogy helps } \\
\text { students to learn the sentence structure that they need } \\
\text { for the writing task. }\end{array}$ & 00 & 20.7 & 3.4 & 27.6 & 48.3 \\
\hline
\end{tabular}


Table 8 illustrates the results for section $\mathrm{C}$ of the questionnaire. Most teachers are of the view that integrated courses can develop the reading and writing abilities of EFL students. They also supported the fact that integrated reading and writing pedagogy can save instructional time. They also agreed upon the statement that in that this approach motivates students to work collaboratively. Most of them strongly agreed that students could learn vocabulary, content, and sentence structure with aligned tasks. None of the teachers strongly disagreed. (See a graphic illustration of each statement in Appendix 4).

\section{Limitations}

The researcher acknowledges the limitations of the research. Firstly, the topics for reading and writing practice were chosen from a limited range of resources due to the cultural restriction. Secondly, limited resources were practically available to the researcher to continue the study longer hence unable to focus on other aspects of the reading and writing skills. The variables like students learning ability to read and write, level of motivation, hours spent on self-study have not been completely controlled for the study.

The study, however, has potential statistical limitations too. Firstly, no statistical analysis technique apart from independent samples and paired samples t-tests is employed. Therefore, there are no supporting results for the level of significance obtained after the analysis. Furthermore, the extensive use of t-tests may result in type I error, questioning the reliability of conclusions. The figures used in the results section contain rounding-off errors as they were rounded off to 2 or 3 decimal places.

\section{Conclusion}

The post-test results indicate that the students in the experimental group performed well $(p<.05)$ in the areas of content and language style when compared to the students in the control group who were not exposed to any kind of integrated reading-writing activities. The obtained results confirm that for a complete teaching semester, the students of the experimental group improved their reading-writing skills because of the integrated reading-writing skills approach. While in contrast, the control group's students did not show any significant improvement in their reading and writing skills because both skills were taught to them separately. The segregated reading-writing skills' teaching approach could not provide much skill development for the control group. In contrast, the integrated reading-writing pedagogy brought a significant betterment in the reading-writing skills of the experimental group's students. A structured questionnaire identifies teachers' perceptions. Most of the experienced teachers are of the view that integrated reading and writing courses can enhance EFL students' learning performance in both language skills.

\subsection{Recommendations for Future Application}

The main aim of this research is to investigate the substantial aspects of teaching English skills with an integrated approach. The researcher believes that this teaching method can be more helpful for students and teachers if adopted and applied in an appropriate direction.

1) The discrete skills teaching methods depending on traditional strategies are passé; therefore, integrated reading and writing skills teaching pedagogy should be adopted to effectuate the academic needs of EFL students in the 21 st century.

2) It is essential to introduce integrated skills activities $s$ in the class, which is quite often neglected by the teacher to save instructional time.

3) The EFL teachers should develop a sense of authorship in their students with purposeful reading instruction.

\section{References}

Ahmed, Y., Wagner, R. K. \& Lopez, D. (2014). Developmental Relations between Reading and Writing at the Word, Sentence and Text Levels: A Latent Change Score Analysis. Journal of educational psychology, 106(2), 419-434. https://doi.org/10.1037/a0035692

Al-Dosari, H. (2016). Effects of an Integrated Reading / Writing Approach on Improving Writing Skills of EFL Students. Dirasat Educational Sciences, 43(1), 759-769. https://doi.org/10.12816/0030028

Alghonaim, A. S. (2018). Explicit ESL/EFL Reading-writing Connection: An Issue to Explore in ESL/EFL Settings. Theory and Practice in Language Studies, 8(4), 385. https://doi.org/10.17507/tpls.0804.04

AlKialbi, A. S. (2015). The Place of Reading Comprehension in Second Language Acquisition. Journal of Literature, Languages and Linguistics, 6(1), 14-21. 
Al-Mansour, N. S. \& Al-Shorman, R. A. (2014). The Effect of an Extensive Reading Program on the Writing Performance of Saudi EFL University Students. International Journal of Linguistics, 6(2), 247. https://doi.org/10.5296/ijl.v6i2.5551

Al-Nasser, A. S. (2015). Problems of English Language Acquisition in Saudi Arabia: An Exploratory-cum-remedial Study. Theory and Practice in Language Studies, 5(8), 1612-1619. https://doi.org/10.17507/tpls.0508.10

AlOmrani, A. H. (2014). Integrating Reading into Writing Instruction in the EFL Programs at Saudi Universities. Arab World English Journal, 5(3), 100-112.

Alrabai, F. (2016). Factors Underlying Low Achievement of Saudi EFL Learners. International Journal of English Linguistics, 6(3), 21. https://doi.org/10.5539/ijel.v6n3p21

Al Zahrani, B. S. \& Elyas, T (2017). The Implementation of Critical Thinking in a Saudi EFL Context: Challenges and Opportunities. IJELTAL (Indonesian Journal of English Language Teaching and Applied Linguistics), 1(2), 133-142.

Amel, S (2015). The Collaborative Learning Strategy as a Tool to Enhance EFL Learners' Writing Skills. A Case Study: Second year Students of English at Mohamed Kheider University of Biskra. A dissertation.

Axelsson, A., Lundqvist, J. \& Sandberg, G. (2019). Influential factors on childrens' reading and writing development: the perspective of parents in a Swedish context. Early Child Development and Care, 1-13. https://doi.org/10.1080/03004430.2019.1590348

Bazerman, C. (1980). A Relationship between Reading and Writing: The Conversational Model. College English, 41(6), 656-661. https://doi.org/10.2307/375913

Benahnia, A. (2016). Why Teaching Writing to EFL Arab Learners is Difficult: a sociocultural overview. KSAALT TESOL Journal.

Andersen, S.C., Christensen, M.V., Nielsen, H.S., Thomsen, M.K., Østerbye, T. \& Rowe, M., (2018). How Reading and Writing Support Each Other Across a School Year in Primary School Children, Contemporary Educational Psychology. https://doi.org/10.1016/j.cedpsych.2018.09.005

Çavdar, G. \& Doe, S. (2012). Learning through Writing: Teaching Critical Thinking Skills in Writing $\begin{array}{lllll}\text { Assignments. PS: } \quad \text { Political } & \text { Science } & \text { 298-306. }\end{array}$ https:/doi.org/10.1017/s1049096511002137

Cho, H. \& Brutt-Griffler, J. (2015). Integrated reading and writing: A case of Korean English language learners. Reading in a Foreign Language, 27(2), 242-261.

Choi, J., Moon, Y., Paek, J. K. \& Kang, Y. (2018). Examining the Relationship between Reading and Writing of Advanced Korean EFL Learners. Korean Journal of Applied Linguistics, 34(1), 91-116. https://doi.org/10.17154/kjal.2018.3.34.1.91

Cao Thị Bạch, M. (2018). Effects of extensive reading on EFL student's writing ability. Truờng Đại học Trà Vinh. http://tvugate.tvu.edu.vn/jspui/handle/TVU_123456789/661

Cumming, A. (2013). Assessing Integrated Writing Tasks for Academic Purposes: Promises and Perils. Language Assessment Quarterly, 10(1), 1-8. https://doi.org/10.1080/15434303.2011.622016

Cunningham, A. E., Perry, K. E. \& Stanovich, K. E. (2001). What Reading Does for the Mind. Journal of Direct Instruction, 1(2), 137-149.

Dubin, F. \& Olshtain, E. (1980). The Interface of Writing and Reading. TESOL Quarterly, 14(3), 353-363. https://doi.org/10.2307/3586600

Elley, W. B. \& Mangubhai, F. (1983). The impact of reading on second language learning. Reading Research Quarterly, 19(1), 53-67.

Elyas, T. \& Picard, M. (2018). A brief history of English and English teaching in Saudi Arabia. English as a Foreign Language in Saudi Arabia, 70-84. https://doi.org/10.4324/9781315688466-3

Fitzgerald, J. \& Shanahan, T. (2000). Reading and Writing Relations and Their Development. Educational Psychologist, 35(1), 39-50. https://doi.org/10.1207/s15326985ep3501_5

Golkova, D. \& Hubackova, S. (2014). Productive Skills in Second Language Learning. Procedia - Social and Behavioral Sciences, 143, 477-481. https://doi.org/10.1016/j.sbspro.2014.07.520 
Grabe, W. (2001). Reading-writing relations: Theoretical perspectives and instructional practices. In D. Belcher \& A. Hirvela (Eds.), Linking literacies: Perspectives on L2 reading-writing connections (pp. 15-47). Ann Arbor, MI: The University of Michigan Press.

Grabe, W. (2003). Reading and writing relations: Second language perspectives on research and practice. In B. Kroll (Ed.), Exploring dynamics of 2nd language writing (pp. 242-262). Cambridge: Cambridge University Press

Greene, S. (1992). Mining a Text in Reading to Writing. Journal of Advanced Composition, 12(1), 151-170.

Hao, X. \& Sivell, J.N. (2002). Integrating Reading and Writing in EFL Composition in China. A Paper presented at the Annual Meeting of the Canadian Association of Applied Linguistics (Toronto, Ontario, Canada). https://files.eric.ed.gov/fulltext/ED468599.pdf

Javid, C. Z. \& Umer, M. (2014). Saudi EFL Learners' Writing Problems: A Move towards Solution. Proceeding of the Global Summit on Education GSE, 4-5.

Khan, I. A. (2011). Learning difficulties in English: Diagnosis and pedagogy in Saudi Arabia. Educational Research, 2(7), 1248-1257.

Koons, H. H. (2008). The Reading-Writing Connection: An Investigation of the Relationship between Reading ability and Writing Quality across Multiple Grades and Three Writing Discourse Modes. A dissertation.

Krashen, S. (1984) Writing: Research, theory, and applications. Oxford, UK: Pergamon.

Li, Z. \& Yang, C. (2014). Reading-to-write: A Practice of Critical Thinking. Journal of Arts and Humanities (JAH), 3(5), 68-71.

Mekheimer, M. A. \& Aldosari, H. S. (2013). Evaluating an Integrated EFL Teaching Methodology in Saudi Universities: A Longitudinal Study. Journal of Language Teaching and Research, 4(6), 1264-1276. https://doi.org/10.4304/jltr.4.6.1264-1276

Miller, B., McCardle, P. \& Long, R. (2012). The Reading-Writing Connection. International Reading Association. https://files.eric.ed.gov/fulltext/ED571549.pdf

Mohammed, Q. \& Rashid, R.A. (2019). The sources of reading comprehension difficulties among Saudi EFL learners. Trends in Social Sciences, 1(1), 7-16.

Ong, J. \& Zhang, L. J. (2013), Effects of the Manipulation of Cognitive Processes on EFL Writers' Text Quality. TESOL Quarterly, 47(2), 375-398. https://doi.org/10.1002/tesq.55

Pardede, P. (2017). Integrated Skills Approach in EFL Classrooms: A Literature Review.

Park, J. (2016). Integrating reading and writing through extensive reading. ELT Journal, 70(3), $287-295$. https://doi.org/10.1093/elt/ccv049

Plakans, L. (2008). Comparing composing processes in writing-only and reading-to-write test tasks. Assessing Writing, 13(2), 111-129. https://doi.org/10.1016/j.asw.2008.07.001

Pysarchyk, O. L. \& Yamshynska, N. V. (2015). The Importance of Integrating Reading and Writing for the EFL Teaching. Advanced Education, 77-83. https://doi.org/10.20535/2410-8286.44298

Shanahan, T. (2006). Relations among Oral Language, Reading, and Writing Development. In C. A. MacArthur, S. Graham \& J. Fitzgerald (Eds.), Handbook of writing research (pp.171-183). New York, NY, US: The Guilford Press.

Shanahan, T. \& Lomax, R. G. (1988). A developmental comparison of three theoretical models of the reading-writing relationship. Research in the Teaching of English, 22(2), 196-212.

Shukri, N.A. (2014). Second Language Writing and Culture: Issues and Challenges from the Saudi Learners' Perspective. Arab World English Journal, 5(3), 190-207.

Smith, F. (1983). Reading Like a Writer. Language Arts, 60(5), 558-567. Retrieved from: http://www.jstor.org/stable/41961505

Sreena, S. \& Ilankumaran, M. (2018). Developing Productive Skills Through Receptive Skills - A Cognitive Approach. International Journal of Engineering \& Technology, 7(4.36), 669-673. https://doi.org/10.14419/ijet.v7i4.36.24220

Tangpermpoon, T. (2008). Integrated approaches to improve students' writing skills for English major students. ABAC Journal, 28(2), 1-9. 
Tierney, R. J., Soter, A., O'Flahavan, J. F. \& McGinley, W. (1989). The effects of reading and writing upon thinking critically. Reading Research Quarterly, 24(2), 134-173. https://doi.org/10.2307/747862

Tsai, J. (2006). Connecting Reading and Writing in College EFL Courses. The Internet TESL Journal, 12(12). Retrieved from: http://iteslj.org/Articles/Tsai-ReadingWritingConnection.html

Y. Durgunoglu, M. Mir \& S. Ariño-Marti (2002). The relationships between bilingual children' reading and writing in their two languages. In: G. Rijlaarsdam (Series ed.) \& S. Ransdell \& M. Barbier (Volume eds.), Studies in Writing: Volume 11: New Directions for Research in L2 Writing, 81-100.

\section{Note}

Note 1. For any information about the appendices, please contact by the email: H.Alhujaylan@gmail.com

\section{Copyrights}

Copyright for this article is retained by the author(s), with first publication rights granted to the journal.

This is an open-access article distributed under the terms and conditions of the Creative Commons Attribution license (http://creativecommons.org/licenses/by/4.0/). 